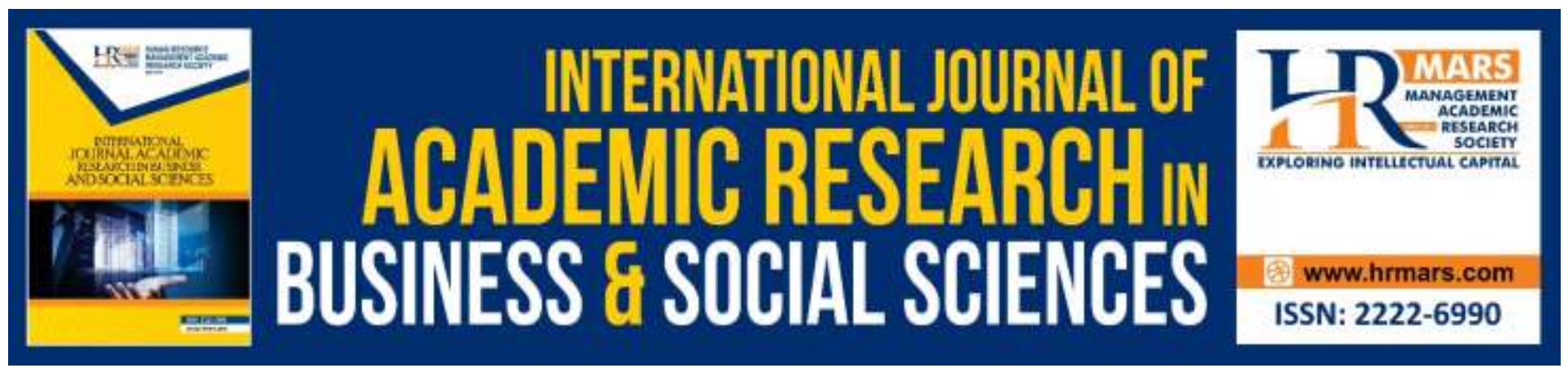

\title{
Determinants of Islamic Banking Stability in Indonesia
}

\author{
Lasty Agustuty D, Stie Tri Dharma Nusantara, Abdul Rakhman Laba, \\ Muhammad Ali, Muhammad Soebarsah
}

To Link this Article: http://dx.doi.org/10.6007/IJARBSS/v9-i7/6158

DOI: $10.6007 /$ IJARBSS/v9-i7/6158

Received: 13 May 2019, Revised: 19 June 2019, Accepted: 02 June 2019

Published Online: 29 July 2019

In-Text Citation: (D, Nusantara, Laba, Ali, \& Soebarsah, 2019)

To Cite this Article: D, L. A., Nusantara, S. T. D., Laba, A. R., Ali, M., \& Soebarsah, M. (2019). Determinants of Islamic Banking Stability in Indonesia. International Journal of Academic Research in Business and Social Sciences, 9(7), 654-669.

Copyright: (C) 2019 The Author(s)

Published by Human Resource Management Academic Research Society (www.hrmars.com)

This article is published under the Creative Commons Attribution (CC BY 4.0) license. Anyone may reproduce, distribute, translate and create derivative works of this article (for both commercial and non-commercial purposes), subject to full attribution to the original publication and authors. The full terms of this license may be seen at: http://creativecommons.org/licences/by/4.0/legalcode

Vol. 9, No. 7, 2019, Pg. 654 - 669

http://hrmars.com/index.php/pages/detail/IJARBSS

JOURNAL HOMEPAGE

Full Terms \& Conditions of access and use can be found at http://hrmars.com/index.php/pages/detail/publication-ethics 




\title{
Determinants of Islamic Banking Stability in Indonesia
}

\author{
Lasty Agustuty D, Stie Tri Dharma Nusantara, Abdul Rakhman Laba, \\ Muhammad Ali, Muhammad Soebarsah \\ Hasanuddin University, Indonesia
}

\begin{abstract}
This paper investigates the main determinants of banking stability in Indonesia. Totaling 11 Islamic commercial banks in Indonesia covering the period between 2013 until 2017. The measure of banking stability is Z-score, thereby allowing analysis of banking stability determinants from three complementary perspectives: competition, bank size, and capital buffer. The method to explain this study is regression. The findings indicate that competition, bank size and capital buffer improve the stability significantly when the level of them increases. The results highlight the importance of institutional quality for banking stability in Indonesia. Banking supervisors in Indonesia countries should consider the role of financial structure and institutional quality for banking stability.
\end{abstract}

Keywords: Bank Stability, Competition, Bank Size, Capital Buffer

\section{Introduction}

Banking stability is one of the factor to advocate national economic growth at this time. As a monetary authority, Bank Indonesia not only maintains monetary stability, but also banking stability. The success of Bank Indonesia in maintaining monetary stability without being followed by banking stability will not be maximized in supporting sustainable economic growth (OtoritasJasaKeuangan, 2014). The stability of the banking system is generally reflected in the sound banking conditions and the functioning of the banking intermediary function in mobilizing public deposits to be spended in the form of credit and other financing to the business world.

In the last 25 years there have been a number of banking vulnerabilities in various countries in the world. Caprio and Klingebiel (2003) recorded 117 cases of systemic banking crises and 51 cases of non-systemic banking crises in developed countries and emerging market countries since 1970. Systemic is defined as a situation where all or most of the capital in the banking system has been eroded (Haldane et al ., 2005). Banking vulnerability certainly raises large $\operatorname{cost}^{1}{ }^{1}$ including in the form of fiscal resolution costs for the government. These costs include various expenses to rehabilitate the

STIE Tri Dharma Nusantara Makassar

Jl. Kumala 2 No. 51

lastyagustuty@gmail.com 
INTERNATIONAL JOURNAL OF ACADEMIC RESEARCH IN BUSINESS AND SOCIAL SCIENCES Vol. 9, No. 7, July, 2019, E-ISSN: 2222-6990 @ 2019 HRMARS

banking system including the cost of bank recapitalization and payments to depositors or savings through a deposit insurance scheme. The financial crisis that occurred in America in 2008 and 2009 in the study of Rosman et al., (2014) shows the weakness of conventional banking systems.

The global economic crisis that occurred in 2008 actually began in the US economic crisis which then spread to other countries around the world, including Indonesia. The American economic crisis began because of the drive for consumption (propincity to consume). The American people live in consumerism beyond the capacity of the income they receive. They live almost in debt, shopping with credit cards, and housing loans. As a result, financial institutions that provide credit are bankrupt because they lose their liquidity, because the company's receivables to housing creditors have been mortgaged to lending institutions. In the end these companies must go bankrupt because they cannot pay all of their debts that are due at the same time. The collapse of these financial companies resulted in the Wall Street stock exchange becoming helpless, large companies could not survive like Lehman Brothers and Goldman Sachs. The crisis continues to spread to the real and non-financial sectors throughout the world.

While in Indonesia by looking to the crisis that struck in 1997-1998, Islamic banks (the first time that was established in Indonesia was Bank Muamalat could prove its resilience in times of crisis, despite experiencing a decrease in profits. Bank Muamalat, which basically uses the principle of profit sharing, survived the crisis due to its varied products, such as the example of Murabahah financing products which were not affected by BI rate fluctuations, so that the real sector that used this financing also survived the adverse impact of the $\mathrm{Bl}$ rate increase. In contrast to what was experienced by conventional banking, which at that time caused 16 banks to be closed (liquidated), then next 38 banks, then 55 banks entered the BTO category under the supervision of BPPN (Agustianto, 2006).

Islamic banking is in more than thirty countries in the world. According to Haz (2006) Islamic banks are not only complementary banks to the conventional banking system but are banks that can be considered as contributing to the economy. The role of Islamic banking is very important for the current economy. In general, the function of Islamic banking is the same as conventional banking, namely as an intermediary institution in the financial sector with the real sector. However, a very striking difference between Islamic banking and conventional banking in its objectives, namely leading to profit oriented. While Islamic banking still aims to bridge the movement of the financial sector in the real sector.

In terms of assets, Islamic banking continues to increase every year. In 2015 amounting to Rp 304 trillion, increased in 2016 to Rp 365.03 trillion and at the end of December 2017 increased to Rp.435.02 trillion. However, not in line with asset growth, Islamic banking experienced a slowdown in growth in third party funds (DPK) and channeled financing (PYD) of Islamic banking. In 2017 Islamic banking deposits grew by $19.83 \%$, a slight slowdown compared to 2016 which reached $20.84 \%$. While the financing provided (PYD) rose 10.69 percent to Rp 281.86 trillion. The Capital Adequacy Ratio (CAR) is at the level of 15.62 percent.

For market share of Islamic banking in Indonesia is still relatively low. As of December 2017, the new Islamic banking market share was 5.78 percent of the total national banking industry. Indonesia should be able to increase market share from Islamic banking in Indonesia. The reason is, Indonesia is a country with the largest Muslim population in the world. So that in its development 
there were problems in competition which became increasingly stringent and triggered a debate over the impact of competition on stability. The fierce of competition encourages banks to take excessive risks which results in increased moral hazard problems. This is due to the bank's lack of caution in fighting over and channeling public funds to increase market share and secure the franchise value that it has, thereby reducing the bank's strength in making profits. As a result, it will increase the instability of Islamic banks (competition-fragility). This is in line with the findings of Berge at al (2008) and Tabak at al (2012).

In Indonesia, total banking assets is an internal factor that are very influential in overcoming financial difficulties in an effort to maintain the stability of the bank itself, for example in the matter of funding distribution. The greater size of the banking indicated by the ownership of a large total assets, will have a greater opportunity to increase the risk that must be borne by the bank. This borne risk is in the form of greater funding distribution. This financing distribution does not result in problematic financing if the composition of funds is sufficient. If the assets owned by the bank are not managed and used optimally for bank operations, the bank has the potential to incur greater asset management costs (Pramudita, 2013).

Based on Cihak and Hesse (2008), Rahim and Zakaria (2013), Khasawneh (2016), and Wibowo (2016) concluded that the size of banks has a significant influence on the stability of Islamic banks. That is, the greater the total assets of the bank, the more stable the Islamic bank will be. While Wahid and Dar's research (2016) revealed that bank size has a negative influence on bank stability. According to him, banks with large total assets will normally be exposed to a large number of risks. Conversely, banks with small assets and limited capacity will not be exposed to a greater number of risks that result in business instability.

Bank Indonesia also plays a role in maintaining the stability of Islamic banks by stipulating the minimum capital ratio that must be maintained by Islamic banks based on the risk profile faced. Capital buffer can be a protector that can absorb various risks of losses that may arise during excessive credit growth and during a crisis period. However, having a high capital buffer means having a high CAR, while a high CAR is not good for the banking industry, because the excess capital can be used to channel credit or investment to maximize profits.

Some studies suggest that capital banks are partially countercyclical and some banks are procyclical. Borio et al., (2001) states that there are two types of bank behaviour regarding capital regulation. First, banks that behave backward-looking and the second are forward-looking. Banks that behave backward-looking tend to continue to increase credit when credit demand is high. This causes banks to be late in anticipating credit risk and must increase capital reserves during the recession period, so that capital reserves or capital buffers are procyclical. On the other hand, banks with forward looking behaviour tend to increase capital reserves while increasing credit when credit demand increases, so banks can anticipate various shocks. This makes capital reserves countercyclical. Ayuso et al (2004) and Jokipii and Milne (2008) find the tendency of smaller banks to behave backward-looking and larger banks behave forward-looking.

Islamic banking capital that continues to improve is reflected in the CAR ratio which reached $17.91 \%$, or an increase of $1.28 \%$ compared to 2016 which reached $16.63 \%$. Islamic banks often try to maintain their capital ratios beyond those required (capital buffers). This is because Islamic banks basically want to secure their stability from a decline in performance. With strong capital, Islamic 
INTERNATIONAL JOURNAL OF ACADEMIC RESEARCH IN BUSINESS AND SOCIAL SCIENCES Vol. 9, No. 7, July, 2019, E-ISSN: 2222-6990 @ 2019 HRMARS

banks are better prepared to anticipate the risk of business failure due to unexpected risks. In addition, with adequate capital, Islamic banks can also meet the provision of financing when demand soars high which has a positive impact on profits. Thus, in this study a research question was asked "Whether competition, bank size, and capital buffer are affect the stability of the Islamic bank?".

\section{Literature Review \\ Banking Stability}

Banking stability is one of the factor to advocate economic growth. As a monetary authority, Bank Indonesia not only maintains monetary stability, but also maintains banking stability to support sustainable economic growth. In Indonesia, currently not only conventional banking, but Islamic banking also plays a role in supporting economic growth.

Saksonova and Solovjova (2012), define bank stability as an ability to run a business while maintaining its business continuity in a different economic environment and not receiving funds from external funding sources to run its business. While Beck (2008) defines the stability of banks as a condition in which banks can carry out their intermediary functions, such as collecting and channeling public funds, as well as providing financial services normally and effectively. The stability of the banking system is generally reflected in the sound banking conditions and the functioning of the banking intermediary function in mobilizing public deposits to be channeled in the form of credit and other financing to the business world. If this condition is maintained, then the process of money circulation and the mechanism of transmission of monetary policy in the economy which mostly takes place through the banking system can also run well. The stability of the banking system will determine the effectiveness of the implementation of monetary policy (UNIMED, 2014).

Banking stability both conventional and sharia can be seen based on the level of banking health. According to Laura at all (2015), many methods can be used to determine the stability of a bank. However, the method that can conclude with higher accuracy and reliability than others is to use a Zscore analysis, especially if applied to large banks. Z-score is basically intended to analyze the possibility of bankruptcy in a company.

Altman (1968) found five types of financial ratios that can be combined to see differences in companies experiencing bankruptcy and stable companies. The combination of the five types of financial ratios is called the Z-Score analysis (Christianti, 2013). The higher the Z-score, the more stable Islamic banks. Boyd at all (2006), states that banks that have a negative Z-score are banks that are bankrupt. Banks that have Zscore near zero tend to be unstable. Whereas banks that have a Zscore are much higher than zero, so they have good stability.

\section{The Relation of Competition to Banking Stability}

The view of competition fragility perspective states that increasingly fierce competition will reduce the bank's strength in making profits and encourage banks to take greater risks in achieving higher profits (Demsetz, Saidenberg, and Strahan (1996), Carletti and Hartmann 2003). Keeley (1990) is a pioneer figure in the view of competition-fragility showing increased competition driven by looser regulations regarding the establishment of bank branches in several states in the United States in the 1980s which eroded bank profits and resulted in a bank bankruptcy wave. 
Some empirical research shows the same results with the traditional views above, such as Jimenez et al (2010) which prove that Spain's increasingly tight banking competition, measured by Lerner index, causes a higher risk of credit portfolios as measured by the level of bank bad loans. Berger et al. (2009) found the same thing in banking data from 30 developed countries. This finding supports the glace that when competition is getting tighter and the bank's profit margin is running low, banks will tend to take excessive risks to increase profits. The credit provided by the bank is decreasing in quality and increasing bank fragility.

Hellmann, Murdock, and Stiglitz (2000) show that competition for deposits can also reduce the bank's cautious attitude. They observed banking crises in the United States and Japan and identified the behaviour of banks that took excessive risks as sources of the banking crisis. According to them the behaviour of banks to take excessive risks was driven by the liberalization of the banking sector which was marked by the abolition of barriers to entry, elimination of the policy of setting a ceiling on deposit rates, and ease in opening new branches.

More recent literature raises different views with the traditional ones. The current view relating to the relationship between competition and stability is called the "competition stability view", competition that is increasingly tight can actually increase bank stability. Boyd and De Nicolo (2005) state that the greater the power (market power) of a bank in the credit market can create even greater risks because higher credit interest rates can make creditors more difficult to pay for these loans and increase moral hazard creditorsto use these credit funds into riskier projects.

The view of "competition-stability" has a different logic with "competition-fragility" views. According to the view of "competition stability, banking stability will actually worsen when the level of competition between banks decreases. Banks that have large market power will tend to set higher loan rates. Stiglitz and Weiss (1981) shows that high interest rates will increase the risk of bank credit portfolios due to adverse selection in bank credit distribution processes where projects financed by banks are classified as poor quality projects. The high cost of funds that must be borne by the company will encourage candidates Low risk creditorsavoid banking funding and seek other funding sources through the capital market with a much lower cost of fund. Prospective creditorswho cannot access funding other than banks, generally because of the risk of their business and projects that are at high risk so that they do not attract investors in the capital market, become bank customers who receive bank credit. The probability of bankruptcy of companies given credit by banks is relatively high and sensitive to changes in the economy and business cycle. The number of bad loans in banks tends to increase and threatens the stability of the banking system

Although both perspectives related to the relationship between the level of banking competition and the strength of banks (market power) with bank stability described above have a contradictory frame of mind, according to Berger et al. (2009) the prediction of both views is not the farthest. Both of these views differ from aspects related to credit risk, but at the risk faced by the bank as a whole, both views have the same prediction. In credit markets that are dominated by banks with large market power, the risk of bank credit portfolios will indeed increase as predicted by the "competitionfragility" view, but overall bank risk does not always go up along with the increase in credit portfolio risk. If banks have enjoyed a high franchise value due to high market power, they will secure the high franchise value from high credit risk with various methods. The bank's strategy to reduce high credit risk can include increasing capital, credit securitization, credit derivatives, smaller credit portfolios 
and increasing bank product diversification, or with other risk mitigation techniques. So if a bank sets a high lending rate so that it has a riskier credit portfolio, the bank can manage the bank's risk as a whole at a relatively lower level.

Based on the explanation, the hypotheses in this study are:

$\mathrm{H} 1$ : Competition has a significant positive effect on Islamic banking stability

\section{The Relation of Bank Size to Banking Stability}

According to Haryanto (2015), total assets can be assessed as a company size that shows whether the companyis big or small. The size of a bank is often used to see the experience and ability of a bank to grow which indicates the ability and level of risk in managing investments provided by stockholders to increase investor prosperity. Bank with large total assets reflect the establishment of the company.

Companies (bank) that have a large company size can increase company value. Large companies have more resources to increase corporate value because they have better access to external information sources than small companies (Hagerman and Ruland in Puspita, 2011). Signaling theory reveals how a company can provide signals to users of financial statements. Brigham and Houston (2006) found that signals are actions taken by company management that provide guidance to investors about how management views the future. For management, companies that have more assets will be easier to use and develop company activities. Whereas for investors will tend to invest their shares in a large company size in the hope of getting a high profit Based on the explanation, the hypotheses in this study are:

$\mathrm{H} 2$ : Bank size has a significant positive effect on Islamic banking stability

\section{The Relation of Capital Buffer to Banking Stability}

In accordance with Bank Indonesia regulations, the ratio of minimum capital requirements is $8 \%$ of risk-weighted assets. The Bank reserves capital buffer to absorb potential losses that can occur so that the position of Minimum Capital Adequacy Obligation (KPMM) can be in accordance with the rules set by the regulator. Capital buffers that have been reserved by the Bank are expected to reduce the risks that arise due to changes in the business cycle. Procyclical capital buffer effect is the Bank's tendency to reduce capital buffers when business cycles improve and increase capital buffers when the business cycle is deteriorating (there is a negative relationship between capital buffers and the business cycle. The rise and fall of capital buffers because such managerial decisions can threaten the stability of the bank if economic and non-economic events that create systemic financial risks that simultaneously companies and banks experience financial difficulties.

Quoted from Noreen et al, the charter value theory made by Marcus (1984) explained that banks always hold extra capital to secure them from a decrease in stability and handle the risk of business failure. This theory also predicts that banks will face losses on their income in the future if bankruptcy occurs and the impact of these losses hit many parties including shareholders. Therefore, the bank will retain its capital in excess of the minimum capital required.

Based on the explanation, the hypotheses in this study are:

$\mathrm{H} 1$ : capital buffer has a significant positive effect on Islamic banking stability 
INTERNATIONAL JOURNAL OF ACADEMIC RESEARCH IN BUSINESS AND SOCIAL SCIENCES

Vol. 9, No. 7, July, 2019, E-ISSN: 2222-6990 @ 2019 HRMARS

\section{Methodology}

\section{Research Design}

This type of research is quantitative research. The sample of this study included Islamic public banks in Indonesia registered in Bank Indonesia which operated from 2013 to 2017. A sample of 11 Islamic commercial banks was obtained. Data is information about the financial condition of Islamic commercial banks in Indonesia which is summarized in a document containing financial statements available online at the official website of the Islamic bank and the website of the Otoritas Jasa Keuangan.

\section{Variable and Measurement}

Dependent Variable

Banking stability is as the dependent variable in this research. The Z-score is a measure of bank insolvency risk calculated at bank level.

$$
Z-S c o r e=\frac{R O A+E / T A}{S D R O A}
$$

Where ROA isthe rate of return on assets, E/TA is equity to total asset ratio and SD-ROA is an estimate of the standard deviation of the rate return on assets. According to Lepetit and Strobel (2013), a high Z-score indicated that the banks are more stable, because it is inversely related to the probability of bank insolvency, in other words, a high Z-score implies lower insolvency risk or improved banking stability (Lepetit and Strobel, 2013).

Table 1 : Interpretation of Z-score

\begin{tabular}{|c|c|}
\hline Z-sroce & Interpretation \\
\hline$Z>2,99$ & bank does not experience problems with financial conditions. \\
\hline $\begin{array}{c}1,8<Z< \\
2,99\end{array}$ & $\begin{array}{l}\text { bank experience a slight problem with financial conditions } \\
\text { (though not serious). }\end{array}$ \\
\hline$Z<1,88$ & $\begin{array}{l}\text { bank experience serious financial problems or experience } \\
\text { defaults. }\end{array}$ \\
\hline
\end{tabular}

Source: Saunders dan Cornett (1994: 318)

\section{Independent Variables}

\section{Competition}

Lerner index is used as an indicator of the degree of market power for the banking sector, which measures banking competition (Beck et al., 2013). Referring to the lerner index formulated by Hawtrey (2008), it is formulated as follows:

$$
\text { Indeks Lerner }=\frac{\text { Total income }+(\text { interest expense }+ \text { non interest operating income })}{\text { total income }}
$$


INTERNATIONAL JOURNAL OF ACADEMIC RESEARCH IN BUSINESS AND SOCIAL SCIENCES Vol. 9, No. 7, July, 2019, E-ISSN: 2222-6990 @ 2019 HRMARS

The Lerner index value ranges from one to zero, with higher numbers indicating greater market power and hence less competition (Tan, 2016). Lerner index represents the extent a bank has market power to set its price above the marginal cost (Tan, 2016). Caminal and Matutes (2002) also suggest that lower competition can lead to reduced credit rationing and larger loans, which can ultimately increase the probability of bank failure, hence greater bank instability.

Size of Bank (Logsize)

Bank size is the total assets owned by the bank. In order for the bank's total asset data to be the same unit as other variable data to narrow diversity, the bank's total assets can be calculated through the following formula:

Total Asset Bank = Logarithm (Total asset)

Capital Buffer

This study calculated the value of capital buffer with the difference between the ratio of capital owned by the Bank and the minimum required capital requirements.

\section{Finding/Discussion}

\section{Descriptive statistics Analysis}

Stability of Islamic Banks in Indonesia

Banking stability in general is reflected in healthy banking conditions and is able to carry out its intermediary function. Following are data of the stability of Islamic banks for the period 2013 to 2017:

Table 2. Z-score Islamic Bank in Indonesia

\begin{tabular}{|c|c|c|c|c|c|}
\hline \multirow{2}{*}{ Bank } & \multicolumn{5}{|c|}{ Tahun } \\
\cline { 2 - 6 } & 2013 & 2014 & 2015 & 2016 & 2017 \\
\hline BMI & 0,96352 & 0,399277 & 0,449343 & 0,429351 & 0,648951 \\
\hline BSM & 1,968678 & 0,035563 & 0,785712 & 0,824209 & 0,824209 \\
\hline BMS & 1,564727 & 0,259937 & 0,296484 & 1,817523 & 1,521466 \\
\hline BRIS & 3,06183 & 0,402948 & 2,12543 & 2,552422 & 1,844512 \\
\hline BBS & 3,568279 & 1,730547 & 4,23061 & 4,113476 & 4,113476 \\
\hline BPS & 0,96706 & 1,803681 & 1,068797 & 0,421562 & $-2,18916$ \\
\hline BVS & 0,355467 & $-0,99969$ & $-1,28775$ & $-1,18916$ & 0,122354 \\
\hline BCAS & 8,598262 & 7,521125 & 9,257241 & 9,838748 & 9,838748 \\
\hline BJBS & 0,274486 & 0,208709 & 0,108235 & $-2,09663$ & $-2,09663$ \\
\hline BNIS & 17,86092 & 16,77531 & 18,68811 & 18,70723 & 18,70723 \\
\hline MBS & 0,314104 & 0,384148 & $-1,87094$ & $-0,8628$ & 1,464727 \\
\hline Mean & 3,590666 & 2,592868 & 3,077388 & 3,146903 & 3,163626 \\
\hline Min & 0,274486 & $-0,99969$ & $-1,87094$ & $-2,09663$ & $-2,09663$ \\
\hline Max & 17,86092 & 16,77531 & 18,68811 & 18,70723 & 18,70723 \\
\hline
\end{tabular}

Source: Data processed from Islamic Bank Financial Reports 
INTERNATIONAL JOURNAL OF ACADEMIC RESEARCH IN BUSINESS AND SOCIAL SCIENCES Vol. 9, No. 7, July, 2019, E-ISSN: 2222-6990 @ 2019 HRMARS

From table 2, it can be seen that the Z-score of each Islamic bank in this study fluctuates annually. The average of the highest Z-score value of Islamic banks in Indonesia is in the value of 3,590666 which occurred in 2013. Meanwhile, Islamic banks with the highest Z-score is Bank Negara Indonesia Syariah (BNIS) in 2016 and 2017 with a value of 18.70723. The lowest average Z-score value occurred in 2014 with a value of 2.592868257 decreased from the previous year with a value of 3,59066647. The Islamic banks that have negative Z-scores are Bank Victoria Syariah, Bank Jabar and Banten Syariah, and Maybank Indonesia Syariah. This happens because the percentage rate of return on assets (ROA) in each bank is very low, which is below 0 and has a negative value so that the resulting Z-score is also low and tends to be unstable.

\section{The Competition of Islamic Banks in Indonesia}

Data of the competition of Islamic banks for the period 2013 to 2017 :

Tabel 3. Indeks Lerner of Islamic Banking in Indonesia

\begin{tabular}{|l|c|c|c|c|c|}
\hline Deskripsi & 2013 & 2014 & 2015 & 2016 & 2017 \\
\hline $\begin{array}{l}\text { Indeks } \\
\text { Lerner }\end{array}$ & 0,1235 & 0,0169 & 0,02305 & 0,0315 & 0,0524 \\
\hline Mean & 0,04947 & & & \\
\hline Std Deviasi & 0,0556 & & & \\
\end{tabular}

Source: Data processed from Islamic Bank Financial Reports

The average Lerner index of Islamic banks is in the range of 0.04947 . This value is close to zero, thus reflecting the tight competition between Islamic banks in Indonesia. Based on these values, the type of competition of Islamic banks is categorized as perfect competition characterized by high demand elasticity values. Therefore, in the Islamic banking competition system, Islamic banks are considered to have less ability to set prices far above the marginal cost because they have relatively weak market power in the market segments it serves.

\section{Bank Size of Islamic Banks in Indonesia}

The size of the bank shows whether the bank is big or small that can be assessed through total assets or fixed assets which are the total of value or worth owned by the bank. The position of total or total assets of Islamic banks can be seen in the balance sheet report. The following data on total assets of Islamic banks for the period 2013 to 2017: 
INTERNATIONAL JOURNAL OF ACADEMIC RESEARCH IN BUSINESS AND SOCIAL SCIENCES Vol. 9, No. 7, July, 2019, E-ISSN: 2222-6990 @ 2019 HRMARS

Table 4. Total Asset of Islamic Banking in indonesia (in thousands of rupiah)

\begin{tabular}{|c|c|c|c|c|c|}
\hline \multirow{2}{*}{ Bank } & \multicolumn{5}{|c|}{ Tahun } \\
\hline & 2013 & 2014 & 2015 & 2016 & 2017 \\
\hline BMI & 53.738 .907 .320 & 2.410 .218 .442 & 57.140.616.713 & 55.786.397.505 & 61.696.919.644 \\
\hline BSM & 63.965 .707 .645 & 66.955 .670 .630 & 70.396 .708 .944 & 78.831 .721 .590 & 87.939.775.355 \\
\hline BMS & 9.125 .210 .428 & 7.044.587.889 & 5.559 .819 .466 & 6.135 .241 .922 & 7.034 .2 \\
\hline BRIS & 17.400 .914 .000 & 20.341 .033 .000 & 24.230 .247 .000 & 27.687 .188 .000 & 31.543. \\
\hline BBS & 4.342 .2 & 5.160 .5 & 5.827.153.527 & 7.019 .598 & 41 \\
\hline BPS & 4.052. & 37 & 75 & 57.9 & 05 \\
\hline BVS & 42 & 6 & 28 & 49 & 721 \\
\hline BCAS & 7 & 6 & 4.349 .5 & 4.995.6 & 5.961. \\
\hline BJBS & 4.6 & 8 & 6.439 .966 & 7.441 .65 & 30 \\
\hline BNIS & 14.708 .504 .000 & 19.492.112.000 & 23.017.667.000 & 28.314 .175 .000 & 34.822. \\
\hline MBS & 2.299 .9 & 2.449 .5 & 1.743 .439 .000 & 1.344.720. & 1.275. \\
\hline Mean & 16.153 .9 & 18.235 .2 & 18.838.063.519 & 20.721.768.028 & 23.304 . \\
\hline Min & 1.323.152.642 & .336 & 79.265 .628 & 1.344 .720 .000 & 275.648 .000 \\
\hline Max & 63.965 .707 .645 & 66.955 .670 .630 & 70.396.708.944 & 78.831 .721 .590 & 87.939.775.355 \\
\hline
\end{tabular}

Source: Data processed from Islamic Bank Financial Reports

Based on table 4, most of the total assets owned by Islamic banks include Bank Syariah Mandiri, Bank Rakyat Indonesia Syariah, Bank Bukopin Syariah, Bank Panin Syariah, Bank Central Asia Syariah, Bank Jabar and Banten Syariah, and Bank Negara Indonesia Syariah continues to increase every year. While other banks tend to fluctuate in total assets throughout the study period. Banks with the largest total assets in 2017 are Bank Syariah Mandiri with total assets reaching Rp $87,939,775,355,000$, while banks with the lowest total assets in 2017 are Maybank Syariah with total assets reaching $\mathrm{Rp} 1,275,648,000,000$. 
INTERNATIONAL JOURNAL OF ACADEMIC RESEARCH IN BUSINESS AND SOCIAL SCIENCES Vol. 9, No. 7, July, 2019, E-ISSN: 2222-6990 ¿ 2019 HRMARS

\section{Capital Buffer of Islamic Banks in Indonesia.}

Table 5. Capital Bufer of Islamic Banking in Indonesia (in persen)

\begin{tabular}{|c|c|c|c|c|c|}
\hline \multirow{2}{*}{ Bank } & \multicolumn{5}{|c|}{ Tahun } \\
\cline { 2 - 6 } & 2013 & 2014 & 2015 & 2016 & 2017 \\
\hline BMI & 6,05 & 5,91 & 2,00 & 2,74 & 3,62 \\
\hline BSM & 6,10 & 6,12 & 2,85 & 4,01 & 5,89 \\
\hline BMS & 4,990 & 11,260 & 10,740 & 14,530 & 13,19 \\
\hline BRIS & 6,490 & 4,890 & 4,940 & 11,630 & 11,63 \\
\hline BBS & 3,100 & 6,800 & 8,310 & 9,000 & 10,20 \\
\hline BPS & 12,830 & 17,690 & 11,300 & 9,170 & 2,51 \\
\hline BVS & 10,400 & 7,270 & 6,140 & 5,980 & 9,29 \\
\hline BCAS & 14,400 & 21,600 & 26,300 & 28,700 & 21,40 \\
\hline BJBS & 9,990 & 7,830 & 11,530 & 8,250 & 8,25 \\
\hline BNIS & 8,540 & 10,760 & 8,730 & 8,420 & 8,42 \\
\hline MBS & 51,410 & 44,130 & 28,400 & 46,060 & 46,06 \\
\hline Mean & 12,21 & 13,13 & 11,02 & 13,49 & 12,77 \\
\hline Min & 3,10 & 4,89 & 2,00 & 2,74 & 2,51 \\
\hline Max & 51,41 & 44,13 & 28,40 & 46,04 & 46,04 \\
\hline
\end{tabular}

Source: Data processed from Islamic Bank Financial Reports

Based on table 5, the average capital buffer of Islamic banks moved fluctuated during the study period and reached the highest point in 2013 with a value of $51.41 \%$. Meanwhile, Islamic bank capital buffers also declined to reach the lowest point in 2015 with a value of $2 \%$. Even so, the average capital buffer per year is never in a negative number so it is still strong enough to reduce and anticipate business risks. Maybank Syariah Indonesia as a Islamic bank with the highest capital buffer with an average of $46.04 \%$ in 2016 and 2017 strongly dominates the acquisition of the average value of Islamic bank capital buffers in Indonesia. Bank Muamalat Indonesia and Bank Syariah Mandiri are Islamic banks with the lowest capital buffer even in 2015, which was at an alarming rate with a capital buffer of $2 \%$.

\section{Hypothesis Testing}

Hypothesis testing uses regression analysis to see the effect of competition, bank size and capital buffer on Islamic banking stability. Test results can be shown in the table below:

Tabel 6. Uji t

\begin{tabular}{|c|c|c|c|c|}
\hline Variable & Coefficient & Std. Error & $\mathrm{t}$ & Sig. \\
\hline Lerner &, 273 & 2,407 & 2,747 &, 008 \\
\hline Logsize &, 225 & 0,044 & 2,201 &, 032 \\
\hline Capital Buffer &, 565 &, 054 & 4,794 &, 000 \\
\hline
\end{tabular}

Source: Data processed (Output SPSS) 
The explanation of the $t$ test table is as follows:

The influence of competition on the stability of Islamic banks

The test results with multiple regression analysis showed indeks lenner value $<5 \%$ significance value $(0.08<0.05)$ so that it can be concluded that competition has a significant influence on the stability of Islamic banks. Thus the proposed hypothesis can be accepted.

The influence of bank size on the stability of Islamic banks

The test results with multiple regression analysis showed bank size $<5 \%$ significance value $(0.032$ $<0.05)$ so that it can be concluded that the size of the bank has a significant influence on the stability of Islamic banks. Thus the proposed hypothesis can be accepted.

The influence of capital buffer on the stability of Islamic banks

The test results with multiple regression analysis showed the value of capital buffer probability $<5 \%$ significance value $(0.000<0.05)$ so that it can be concluded that capital buffer has a significant influence on the stability of Islamic banks. Thus the proposed hypothesis can be accepted.

\section{Discussion}

\section{The Influence of Competition on the Stability of Islamic Banks}

Based on the results of the test, the competition between Islamic banks has a significant positive effect on the stability of Islamic banks in Indonesia. This means that if the level of competition becomes tighter, the stability of Islamic banks will increase. This fact supports the view of competition-stability which assumes that the more competitive market competition between Islamic banksfunds distribution will make the rate of return requested by banks to their financing customers will be lower, thereby reducing the likelihood of customer default risk (risk shifting paradigm).

This result is in line with the findings of Schaeck and Cihack which show that banks competition can have a positive effect on the level of health through efficiency transmission. These results also reinforce the results of Beck et al's research which states that increasing competition has an impact on the low likelihood of bank bankruptcy, making deposit returns better and making the system of credit information more effective.

Significantly the influence of competition between Islamic banks on the stability of Islamic banks in Indonesia is also because basically, normatively, Islamic banks position themselves as business people who uphold business morals and ethics that breathe Islamic values in their business activities (uswatun khasanah). Islamic banks always prioritize healthy competition to encourage perfect competition, especially competition between Islamic banks. Therefore, increasingly competitive business competition will encourage Islamic banks to behave competitively as well. In addition, Islamic banks are not allowed to have an anti-competition attitude by using their market power to maximize revenue. If Islamic banks are anti-competitive and exploit the market with its market power, it will have an impact on the level of concentration of the Islamic banking industry which is increasingly high and causes reduced competition due to business domination.

The aim of Islamic banks to create justice in the economic aspect and improve the quality of life of the people by opening greater business opportunities will not be achieved and will increase the possibility of bankruptcy of other Islamic banks due to not being able to compete due to lack of adequate market power. Such conditions are in line with the structure conduct performance theory 
which suggests that more banks in a banking market will generally lead to highly competitive bank behaviour that will reduce prices and increase optimum output levels. This indicates that the Islamic banking market is not concentrated in Indonesia will produce very competitive performance. The ratio of the rate of return to costs will be lower which results in higher customer satisfaction that will increase the profitability of Islamic banks so that the stability of Islamic banks is getting stronger.

Furthermore, the effect of significant positive competition on the stability of Islamic banks is likely due to the relatively low diversity of Islamic banks due to the lack of Islamic banks' flexibility in creating new products and the ease with which products are created to replicate and tend to market segmentation. Such conditions will lead to the perception that between one Islamic bank and another Islamic bank is the same, not much different. As a result, a positive domino effect will occur in the Islamic banking business system, as the presumption of stability of a sharia bank that is better than a conventional bank will make a similar assumption to other Islamic banks.

\section{The Influence of Bank Size on Stability of Islamic Banks}

The results showed that the bank size variables proxied through total bank assets had a significant positive effect on the stability of Islamic banks. This indicates that the greater the total assets owned, the stability of Islamic banks will be stronger. Banks with large total assets can manage risks well because they are accustomed to asset management activities. Good asset management can be beneficial to banks so that they avoid problems of liquidity, leverage and capital so that they can support operational activities, carried out and increase the level of stability of the bank (Hasanatina, 2016). The results of this study are in line with research conducted by Cihak and Hesse (2008), Rahim and Zakaria (2013), and Wibowo (2016) which states that total assets of banks have a significant influence on the stability of Islamic banks.

The tight regulation specifically designed to oversee Islamic banking (well regulated.) Islamic banks are not free to engage in business areas that are full of risks and take greater risks just to increase the expected benefits. In addition, large Islamic banks tend to be more stable because in Indonesia, there are special treatments for banks that are categorized as large assets in terms of capital, both BUKU 3 and BUKU4 categories. Banks that are in this category are permitted to conduct all business activities in rupiah and foreign exchange. Banks that are included in BUKU 3 can make 25\% investments in limited domestic and foreign financial institutions in the Asian region, while for banks including BUKU 4, they can invest $35 \%$ in domestic and foreign financial institutions with widerregional coverage.

According to Signaling Theory that reveals how a company can provide signals to users of financial statements. The larger the size of a bank, it can be a signal that the company has good performance and is able to face risks Brigham and Houston (2006) found that signals are actions taken by company management that provide guidance to investors about how management views the future.

\section{The Influence of Capital Buffer on Stability of Islamic Banks}

The results showed that the variable capital buffer had a significant positive effect on the stability of Islamic banks. Based on the results of the study it can be said that the greater the capital buffer owned by Islamic banks, the stronger the stability. Capital buffers that have been reserved by the 
Bank are expected to reduce the risks that arise due to changes in the business cycle (Wibowo, 2016). With the capital buffer owned by Islamic banks, Islamic banks can anticipate financial difficulties in the future so that the stability of their business will not decline.

The results of this study are in line with the research conducted by Wibowo (2016) which states that capital buffers have a significant influence on the stability of Islamic banks. This research is also in line with the charter value theory which states that banks always hold extra capital to secure them from the risk of business failure. The positive influence of capital buffer on the stability of Islamic banks is also suspected because by holding more capital than required, Islamic banks will find it easier to get funds that can be used at any time. Islamic banks can avoid the use of external funding sources that have a costly fund that is quite expensive and not so profitable (the pecking order theory). Therefore, Islamic banks tend to use their own capital in an effort to reduce losses due to implicit and explicit costs that occur during the research period to maintain the business continuity of Islamic banks.

\section{Conclusion}

Based on the analysis and discussion of the results of study regarding the effect of competition, bank size and capital buffer on the stability of Islamic banks in Indonesia, it can be concluded as follows:

A. Competition variables have a significant positive effect on the stability of Islamic banks. These results prove that the perspective of competition-stability is more in line with the market conditions of Indonesian Islamic banks compared to competition-fragility views

B. Bank size variables have a significant positive effect on the stability of Islamic banks. This result proves that the signalling theory.

C. The variable capital buffer has a significant positive effect on the stability of Islamic banks. This result is consistent with the aim of establishing a capital buffer, which is to strengthen Islamic banks to be more stable when facing extreme market changes and absorb losses that can be caused by the negative impact of the economic and financial crisis shock.

\section{Implication}

This study only analyzes the level of stability in Islamic banks, so that for further research can be directed to compare the level of stability between conventional and sharia banks with the period of research before and during the crisis. In addition, the stability of a bank needs to include risk factors that can trigger correlated defaults between banks or what is referred to as systemic risk.

\section{Contribution}

This research is expected to be an input for the Government as an economic policy maker and Bank Indonesia as a regulator that can help evaluate banking regulations specifically related to financial risk policy and banking stability. 
INTERNATIONAL JOURNAL OF ACADEMIC RESEARCH IN BUSINESS AND SOCIAL SCIENCES

Vol. 9, No. 7, July, 2019, E-ISSN: 2222-6990 ¿ 2019 HRMARS

\section{References}

Ayuso, J., Pe'rez, D. \& Saurina, J. (2004). Are capital buffers pro-cyclical? Evidence from Spanish panel data. Spain, Banco de Espana. Elsevier.

Beck, T., Jonghe, O. D. \& Schepens, G. (2013). Bank Competition and Stability: Crosscountry Heterogeneity. Netherlands. Elsevier.

Brigham, E. F., \& Houston, J. F. (2012). Dasar-dasar Manajemen Keuangan (edisi 11). Jakarta: Salemba Empat

Cihack, M. \& Hesse, H. (2008). Islamic Banks and Financial Stability: An Empirical Analysis. Malaysia. IMF Working Paper Series.

Hawtrey \& Liang. (2008). Bank interest margins in OECD countries. North American Journal of Economics and Finance. Elsevier.

Khasawneh, A. Y. (2016). Vulnerability and Profitability of MENA Banking System: Islamic Versus Commercial Banks. International Journal of Islamic and Middle Eastern Finance and Management. Emerald

Pramudita, A. (2013). Pengaruh Ukuran Bank, Manajemen Aset Perusahaan, Kapitalisasi Pasar dan Profitabilitas terhadap Kredit Bermasalah pada Bank yang Terdaftar di BEI. Jurnal IImiah Fakultas Ekonomi dan Bisnis Universitas Brawijaya.

Rahim, Mat, S. R., \& Zakaria, R. H. (2013). Comparison on Stability Between Islamic and Conventional Banks in Malaysia." Malaysia. Journal of Islamic Economics, Banking and Finance.

Saksonova \& Solovjova. (2012). Some Quantitative Aspects of Stability Management Strategy in a Bank Procedia-Social and Behavioural Sciences. University of Latvia, Latvia. Elsevier.

Saunders, A., \& Cornett, M. M. (1994). Financial Institution Management: A Risk Management Approach (sixth edition). New York: McGraw-Hill Companies.

Tabak, B. (2012). The relationship between banking market competition and risk-taking Do size and capitalization matter?, Journal of Banking and Finance. Elsevier.

Tan, Y. \& Anchor, J. (2016). Stability and profitability in the Chinese banking industry: evidence from an auto-regressive-distributed linear specification. UK. Investment Management and Financial Innovations.

Wahid, A. M. \& Dar, H. (2016). Stability of Islamic versus Conventional Banks: A Malaysian Case. Malaysia. Jurnal Ekonomi Malaysia

Wibowo, B. (2016). Stabilitas Bank, Tingkat Persaingan Antar Bank dan Diversifikasi Sumber Pendapatan: Analisis Per Kelompok Bank di Indonesia. Jurnal Manajemen Teknologi. Institude Teknologi Bandung 